\title{
PERAN NGO DALAM UPAYA PENGUATAN GLOBAL ENGAGEMENT WARGA NEGARA UNTUK MERESPON KRISIS HAM GLOBAL
}

\author{
Oleh: \\ A. ACO AGUS ${ }^{1}$, MUHAMMAD HAIDIR ${ }^{2}$, SUDIRMAN ${ }^{3}$ \\ ${ }^{1}$ Universitas Negeri Makassar, e-mail: andi.aco.agus@unm.ac.id \\ ${ }^{2}$ Madrasah Aliah DDI Padanglampe Kabupaten Pangkep \\ ${ }^{3}$ Madrasah Aliah DDI Padanglampe Kabupaten Pangkep, \\ e-mail: sudirmansetta@gmail.com
}

\begin{abstract}
ABSTRAK: Tulisan ini mengkaji intervensi yang dilakukan NGO terhadap penguatan global engagement warga negara di Indonesia. Globalisasi merupakan proses negara yang mendunia, yaitu bahwa setiap negara saling bergantung, saling memengaruhi dan berinteraksi tanpa mempermasalahkan batas-batas teritorial negara dengan mengandalkan kecanggihan teknologi dan percepatan informasi. Luhan (1994) mencuatkan istilah "global village" untuk mendeskripsikan dunia sebagai tempat tinggal yang semakin sempit karena masyarakatnya sudah terhubung satu sama lain melalui teknologi informasi dan komunikasi (hlm. 5). Sejalan dengan itu, globalisasi memberikan kita tambahan kedudukan sekaligus hak dan kewajiban yakni sebagai warga global atau yang biasa disebut global citizen. Global citizen dijelaskan sebagai "... one who can live and work effectively anywhere in the world, supported by a global way of life" (Noddings dalam Rapoport, 2009). Salah satu dari tiga dimensi utama dalam global citizeship ialah keterlibatan kewargaan global (global civic engagement) yang dimaknai sebagai tindakan atau kecenderungan untuk mengenali masalah-masalah kemasyarakatan baik di tingkat lokal, nasional dan global dengan ikut serta dalam aktivitas dan partisipasi masyarakat. (Murdiono, 2014). Artikel ini mencoba melaporkan studi kualitatif yang berfokus pada kegiatan Global Humanitarian Agency yang disebut Aksi Cepat Tanggap (ACT) untuk memperkuat keterlibatan kewargaan global di Indonesia. Penelitian ini menggunakan pendekatan kualitatif dengan desain deskriptif. Data diperoleh dari berbagai teknik seperti wawancara, observasi, dan studi dokumen. Hasil penelitian menunjukkan bahwa Badan Kemanusiaan Global ACT bertindak secara aktif memfasilitasi warga Indonesia dalam mengaktualisasikan keterlibatan warga global melalui (1) pemberian pengetahuan tentang isu kemanusiaan global terbaru; (2) menciptakan ruang publik di media sosial untuk membahas isu kemanusiaan, (3) aktivitas filantropi; dan (4) voluntarisme global. Aktivitas kemanusiaan ini memposiskan Lembaga Kemanusiaan Global ACT sebagai civic community yang tidak hanya mampu melakukan penguatan global civic engagement, tetapi juga mampu membangun jejaring transnasional, dan sebagai inovator model alternatif pembangunan masyarakat berbasis solidaritas global.
\end{abstract}

\section{KATA KUNCI: Global Civic Engagement, Civic Community, Konflik HAM global}

ABSTRACT: This article attempts to describe the intervention of NGO in strengthening global engagement in Indonesia. Globalization is a global state process, that is, each country is interdependent, influencing and trusting territorial borders by relying on technological sophistication and accelerating information. Luhan (1994) raises the term "global village" to describe the world as an increasingly complex place of residence because its people have been connected with each other through information and 
communication technology (p. 5). In line with that, globalization gives us an additional temporary position of rights and is surrendered as global citizens or commonly called world citizens. Global citizens discuss as "... someone who can live and work effectively anywhere in the world, supported by a global way of life" (Noddings in Rapoport, 2009). One of the three main dimensions of global citizenship is a global engagement of the citizens that is interpreted as an action or interest in overcoming social problems at the local, national and global level by participating in every activity and society. (Murdiono, 2014). This article try to report the qualitative study which focused on activities of the Global Humanitarian Agency called Aksi Cepat Tanggap (ACT) in order to strengthen global engagement in Indonesia. This research use qualitative approach with descriptive design. Data are obtained from various thechniques such as interviews, observation, and study of documents. The results of the study show that ACT's Global Humanitarian Agency acts actively facilitating Indonesian citizens in actualizing global engagement through (1) providing knowledge of the latest global safety issues; (2) creating public space on social media to discuss aid issues, (3) philanthropy activities; and (4) global voluntarism. This welfare activity positions the ACT Global Humanitarian Institution as a community civic which not only able to strengthen global civic engagement, but also noted as contributors to establishing transnational links and as innovators of alternative social development models based on global solidarity sense.

\section{KEYWORDS: NGO, Global Engagement, Global Humanitarian Crises}

\section{PENDAHULUAN}

Negara demokrasi Indonesia mensyarakatkan keterlibatan warga negara sebagai pilar yang kokohnya kemadadian dan keadialn sosial. Bicara mengenai keterlibatan warga negara bukan sekadar partisipasi politik melalui pemilihan umum atau proses mempengaruhi kebijakan saja. Bicara keterlibatan warga negara juga tidak sebatas pada ruang lokal saja, tetapi secara luas pada ruang global. Karena pada hakikatnya, demokrasi mengandung definisi yang kompleks termasuk didalamnya aspek-aspek kehidupan bermasyarakat yang melembaga dalam perilaku sehari-hari warganegara. Sebagaimana disepakati oleh para ahli bahwa keterlibatan warga negara merupakan suatu kondisi atau norma dimana warga negara secara individual ataupun kolektif berpartisipasi aktif di kehidupan bermasyarakat berdasarkan keterampilan, keahlian, pengetahuan, yang berkombinasi dengan nilai-nilai, motivasi dan komitmen untuk melakukan perubahan dalam rangka meningkatkan kualitas hidup masyarakat menjadi lebih baik. (Jacoby, 2009; Adler \& Goggin, 2005; Ehrlich, 2000; Carpini \& Keeter, 1996). Studi ini berangkat dari hasil telaah yang dilakukan peneliti terhadap beberapa penelitian, artikel jurnal ilmiah, serta berbagai data dan informasi yang terpublikasi yang menunjukkan masih perlunya peningkatan keterlibatan warga negara untuk menjawab masalahmasalah kemanusiaan pada tingkat global. Gejala permasalahan dilapangan yang menujukkan bahwa:

Pertama minimnya kesadaran dan kesediaan warga negara atau masyarakat untuk melibatkan diri dalam penanganan ataupun pengentasan isu-isu kemanusiaan baik pada tingkat lokal, regional maupun global. Tren perilaku masyarakat hari ini menujukkan sikap apatisme terhadap permasalahan kehidupan sosial dna kemanusiaan. Sikap acuh tak acuh yang ditampilkan menandakan mereka seolah menutup 
mata dan telinga terhadap krisis kemanusiaan yang sedang berlangsung. Kesediaan individu warga negara maupun masyarakat untuk berkontribusi dalam aktivitas voluntarisme masih sangat minim. Secara kontradiktif, Affandi (2009) mengemukakan bahwa salah satu karakteristik warga negara yang disepakati para pakar yaitu kemampuan untuk melihat dan mendekati masalah-masalah sebagai warga bangsa dan sebagai warga global.

Kedua ketidak-optimalan institusi dan implementasi kebijakan untuk mewadahi keterlibatan warga negara pada aktivitas voluntarisme kolektif dibidang sooal-kemanusiaan di Indonesia. Kita dapati pelbagai program pemerintahan yang dimaksudkan untuk tujuan-tujuan sosial, namun belum cukup mampu memobilisasi masyarakat dalam jumlah besar sehingga upaya mempengaruhi kebijakan penuntasan isuisu kemanusiaan belum memadai. Padahal masyarakat indonesia memiliki modal sosial yang cukup baik dari segi sumber daya maupun kualitas mutual cooperationnya. Fakta di lapangan menujukkan bahhwa kesediaan warga negara untuk menjadi anggota dalam komunitas mengaktualisasikan voluntarisme kolektif masih perlu untuk dibangun lagi. Padahal warga negara terutama kaum muda sebagai generasi produktif harusnya memiliki spirit pelayanan yang kuat bagi masyarakat. Warga negara dewasa ini harus mampu ambil peran dan menyeimbangkan antara gerakan intelektual, gerakan moral, dan gerakan sosial. Krisis keterlibatan warga negara dalam aktivitas pelayanan, pengabdian, pemberdayaan dan penegakkan HAM harus menjadi perhatian bersama.

Gejala sosial dilapangan menujukkan bahwa krisis kemanusiaan baik pada tingkat lokal, regional, maupun global kian kompleks. Masalah yang meliputi kemiskinan dan keterlantaran yang diakibatkan oleh konflik global yang menimpa beberapa negara membutuhkan keterlibatan warga global. Sebut saja, konflik Israel-Palestina, konflik Suriah, konflik Yaman, konflik Rohingya, konflik Uighur. Pada 2016, dilaporkan oleh Lembaga Studi Stategis Internasional (IISS) bahwa korban tewas akibat konflik global telah mencapai 167.000 jiwa (diakses dari http://nasional.kompas.com, Desember 2018). Angka tersebut tentunya terus bertambah setiap harinya hingga detik ini. Bangsa Indonesia sebagai bangsa yang secara konstitutif mencita-citakan perdamaian dunia yang dijiwai oleh prinsip kemanusiaan dan keadilan sosial semestinya memberikan kontribusi terbaik dengan modal sosial dan sumber daya yang ada. Kontribusi dalam upaya pengentasan atau setidaknya upaya mengurangi penderitaan para korban akibat konflik perang maupun korban aparteid diberbagai belahan dunia haruslah terus ditingkatkan.

Permasalahan-permasalahan seperti yang dikemukakan membutuhkan upaya represif yang sinergis lintas sektoral baik dari pemerintah maupun berbagai elemen masyarakatnya. Peran warga negara menjadi urgen ditengah keterpurukan sosial. Warga negara dalam kaitannya dengan penanganan keterpurukan sosial baik yang sifatnya struktural maupun kultural harus bersikap kolaboratif dengan pemerintah atau bahkan mampu secara mandiri mengembangkan keterlibatannya. Maka kehadiran organisasi non pemerintah ynag mengembangkan gerakan sukarela yang mampu berperan sebagai penyalur modal sosial menjadi urgen ditengah tragedi krisis kemanusiaan global. Keterlibatan warga negara melalui gerakan-gerakan dibidang sosial dan kemanusiaan menjadi sangat berarti untuk melawan apatisme dan 
individualisme yang menjangkit warga negara. Studi ini adalah studi PKn pada domain sosio kultural yang memfokuskan peran NGO sebagai inisiator pengembangan program-program voluntarisme dalam menggalang keterlibatan warga negara. Adapun dalam penelitian ini keterlibatan dipahami sebagai respon, rekasi dan partisipasi warga negara dalam gerakan-gerakan solidaritas global baik pada ranah daring maupun luring. Studi ini setidaknya diilhami oleh dua hal. Pertama, bahwa konsepsi voluntarisme adalah akar demokrasi dimana didalamnya warga negara bertindak reaktif dan responsif dan memiliki spirit pengabdian yang tinggi. Warag negara bertanggungjawab dalam pembangunan kualitas kehidupan masyarakat. Stigma bahwa penanganan masalah kemanusiaan global ssulit dilakukan karena jauh dari jangkauan dan stigma bahwa upaya penyelesaian masalah tersebut bukan merupakan kewajiban sipil sebagai warga bangsa haruslah segera diputus mata rantainya. Maka melalui penelitian ini, diharapkan diperoleh gambaran tentang pentingnya pengembangan program-program kerelawanan global untuk membumikan gerakan solidaritas global bagi warga negara Indonesia.

\section{The Integrative Theory of Civic Engagement}

Salah satu definisi civic engagement yang paling banyak dikutip adalah pendapat Carpini dan Keeter (1996) yang mendefinisikannya sebagai "civic engagement is individual and collective actions designed to identify and address issues of public concern" (dalam Pancer, 2015, hlm. 3). Definisi ini secara tegas mengidentikan keterlibatan warga negara adalah untuk penanganan masalah-masalah publik. Pengertian ini masih terbilang sederhana jika dibandingkan dengan definisi lainnya. Ehrlich dalam Civic Responsibility and Higher Education mendefinisikan Civic engagement sebagai upaya yang bertujuan untuk menciptakan perubahan dalam kehidupan kewarganegaraan dari sebuah masyarakat dengan mengembangkan pengetahuan, keterampilan, nilai-nilai, dan motivasi tertentu. Keterlibatan ini dimaksudkan untuk mendukung dan meningkatkan kulaitas kehidupan bermasyarakat baik dalam proses politik maupun nonpolitik (2000, hlm. vi). Pada definisi ini cukup jelas aktivitasnya lebih meluas dari sekedar penanganan permasalahan sosial seperti definisi dari Carpini. Aktivitas tersebut bisa partisipasi pada kegiatan budaya dan seni ataupun organisasi, tentu aktivitas tersebut untuk meningkatkan kualitas kehidupan masyarakat, bukan sekedar "address issues of public concern" belaka.

Pendefinisian Civic engagement bergantung pada perspektif dan kepentingan pembuat definisinya. (Jacoby, 2009; Adler \& Goggin, 2005). Mengutip pendapat Jacoby (2009) bahwa "civic engagement is a complex and polyonymous concept", mengingat para praktisi dan sarjana masih menggunakan bermacam-macam nama untuk hal ini. Ramaley menjabarkan perspektif dan kepentingan civic engagement yang dimaksud antara lain; Civic engagement as community service, Civic engagement as collective action, Civic engagement as political involvement dan terakhir Civic engagement as social change. (Adler \& Goggin, 2005). Untuk itu ia mencontohkan dan membaginya secara spesifik menjadi beberapa perspektif yaitu: (1) Civic engagement as community service, yaitu civic engagement diartikan sebagai tugas dan kewajiban individu untuk merangkul dengan tanggung jawab kewarganegaraan untuk secara aktif 
berpartisipasi, secara individu atau bersama dengan orang lain, dalam kegiatan pelayanan sukarela yang memperkuat masyarakat setempat; (2) Civic engagement as collective action, yaitu civic engagement diartikan sebagai kegiatan di mana orang-orang datang bersama-sama dalam peran mereka sebagai warga negara. Disini seorang individu, melalui tindakan kolektif, mempengaruhi masyarakat sipil yang lebih besar; (3) Civic engagement as political involvement, yaitu civic engagement diartikan sebagai upaya individu dengan tindakan kolektif untuk memecahkan masalah melalui proses dan jalan politik dimana melibatkan partisipasi aktif dan kepemimpinan dalam kehidupan publik; (4) Civic engagement as social change yaitu civic engagement diartikan sebagai partisipasi dalam kehidupan masyarakat dalam rangka untuk membantu membentuk masa depan dengan perubahan sosial.

Dari pemaparan dari Ramaley tersebut, dapat dikatakan bahwa spektrum dari civic engagement cenderung meluas. Para ilmuwan dan praktisi menggunakan beragam istilah sesuai dengan konsep yang dituju dan digunakan. Lebih jauh Jacoby memperluas cakupannya dengan statemen "Civic Engagement is defined as acting upon a heightened sense of responsibility to one's communities". (Jacoby, 2009, hlm. 9). Civic Engagement dalam pengertian tersebut meliputi rasa tanggung jawab yang mendorong partisipasi untuk membangun masyarakat madani, serta untuk memberikan manfaat untuk kebaikan bersama. Bagian yang esensial dari civic engagement adalah rasa tanggung jawab pada sesuatu yang lebih dari sekedar kepentingan pribadi (Lawry, Laurison, \& Van Antwerpen, 2006). Untuk mempersempit batasan dari spektrum civic engangment bagan berikut merupakan skema Integrative Theory of Civic Engagement: 


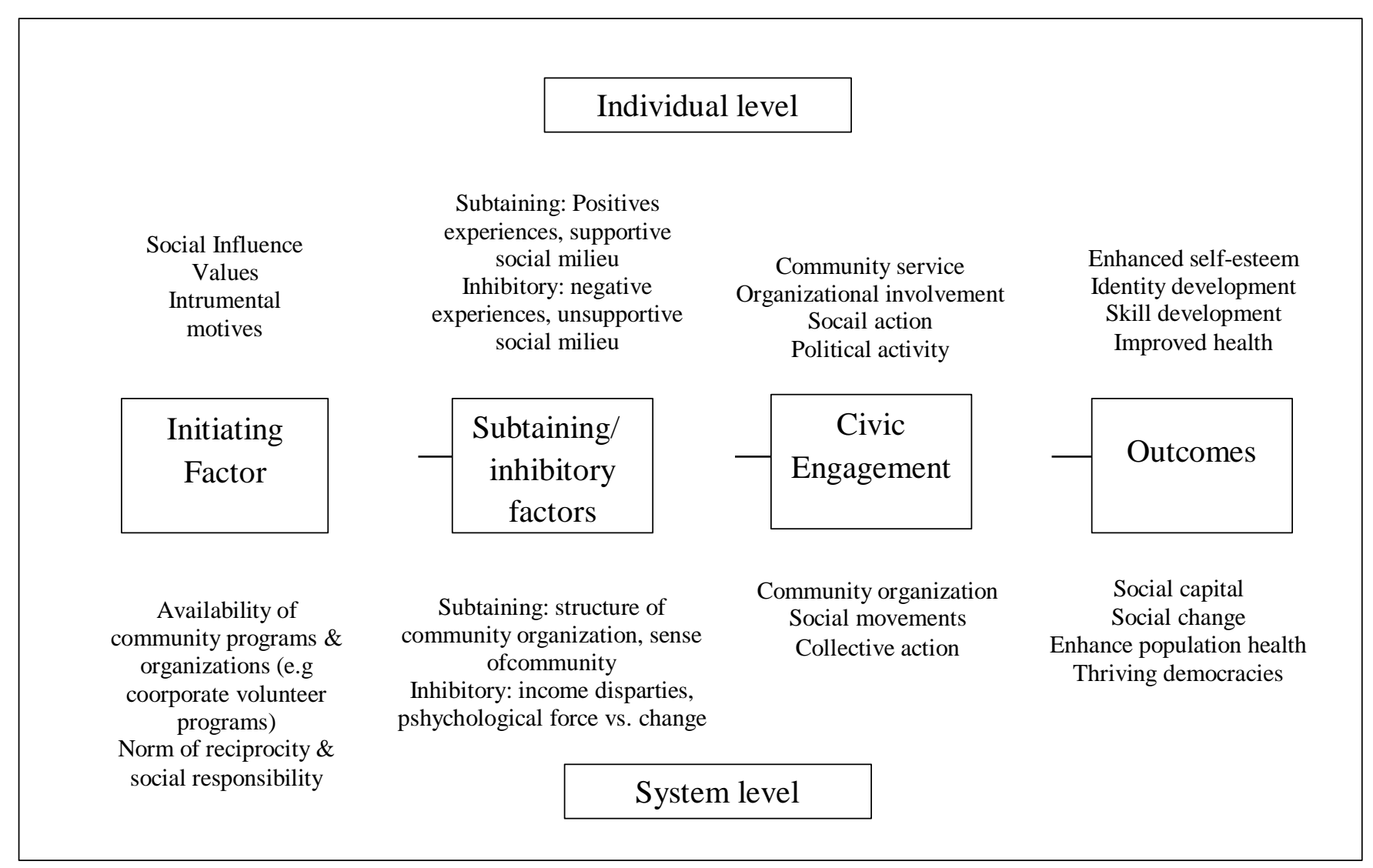

Sumber: Pshychology of Citizenship and Civic Engagement (Pancer, 2015)

Bagan di atas memperlihatkan proses civic engagement yang secara garis besar terbagi menjadi dua level, yakni individual level dan system level. Pada idividual level orang menjadi terlibat secara civically sebagai akibat dari berbagai faktor penyebab, dan yang paling menonjol adalah pengaruh sosial (social influence), nilai-nilai idividu (the individual values), dan motif instrumental. Sedangkan dalam system level, civic engagment banyak dipengaruhi oleh sistem sosial (keluarga, masyarakat, lingkungan kerja, lingkungan belajar, lingkungan bermain dan ibadah). Berdasarkan teori ini, keterlibatan warga negara didorong oleh initiating factor dan subtaining factor. Studi ini bermaksud mengkaji initianting factor dari civic engagement pada level sistem yaitu ketersediaan dari organisasi dan program kemasyarakatan yang dalam hal ini diperankan oleh NGO bernama Aksi Cepat Tanggap. NGO ini memiliki kedudukan dan peran besar dalam proses pembangunan masyararakat baik pada konteks lokal maupun global. Beberapa literatur menyebutkan bahwa meskipun kiprah NGO berkembang sesuai dengan perubahan kemajuan waktu, pada intinya NGO berperan sebagai mitra pemerintah dalam program pembangunan (Willets, 1996; Grugel, 2000; Yamin, 2001). Di Indonesia, NGO bertindak sebagai penyokong (supporter) dan sekaligus pelaksana (executor) program pengembangan masyarakat berdasarkan eksistensi kedekatan lembaga ini dengan masyarakat.

\section{Global Engagement Warga Negara}

$$
\text { Dalam }
$$
mengkonstruk pemahaman tentang kewarganegaraan 
global, langkah pertama yang harus ditempuh ialah memahami perbedaan konsep kewarganegaraan global dan globalisme. Kewarganegaraan bukanlah konsep globalisme yang oleh para ahli diyakini sebagai paham yang mengikis nasionalisme. (Hendrastomo, 2007). Globalisme yang dibawa seiring dengan globalisasi telah membawa kita pada perubahan sosial yang masif. Barber (1995) menyebut globalisme yang kemudian ia istilahkan dengan McWorld sebagai konsekuensi dari kecenderungan global yang merupakan permasalahan dan tantangan baru di era pascamodern Globalisme menurutnya merujuk pada nilai-nilai korporat pascanasional atau bahkan antinasional. Sehingga Barber berpandangan bahwa kapitalisme global sebagai dampak dari globalisme justru cenderung melawan konsep kewarganegaraan. (dalam Kalidjernih, 2013). Maka secara terang-terangan dapat dikatakan bahwa globalisme jauh berbeda dengan konsep kewarganegaraan global. Kewarganegaraan global merupakan konsep yang memuat dan menggariskan tatanan hak dan kewajiban yang harus dipenuhi sebagai warga dunia tanpa mengesampingkan peran sebagai warga bangsa atau bahkan pada kasuskasus tertentu justru menguatkan peran dan identitas sebagai warga bangsa.

Green (2012) merumuskan definisi global citizenship dengan melihat beberapa perspektif, yakni: Pertama, Global citizenship as a choice and a way of thinking. Definisi ini berangkat dari pemikiran bahwa status kewarganegaraan global berbeda dengan identitas nasional yang melekat sejak kelahiran. Status ini diterima secara sukarela yang kemudian mendatangkan konsekuensi hidup berdampingan dengan masyarakat yang beragam. Praktik kewarganegaraan global dalam pengertian ini adalah melalui keterlibatan diri dalam isu-isu global, atau melibatkan diri dalam kebudayaan yang berbeda dalam sebuah setting lokal; Kedua, Global citizenship as self awarness and awarness of orthers. Definisi ini merujuk pada kesadaran diri yang mendorong seseorang untuk lebih memahami hakikat manusia yang lebih universal dan memelihara nilai-nilai kemanusiaan yang sama dan atas dasar itu semua orang memilki tanggung jawab yang sama pula. Ketiga, Global Citizenship as they practice cultural empathy. Empati budaya atau kompetensi interkultural secara umum diartikulasikan sebagai sebuah tujuan dari pendidikan global. Adapun kompetensi interkultural menjadi kompetensi sentral yang hendak dibentuk pada kurikulum perguruan tinggi sebagai bentuk pendidikan kewarganegaraan global. Kompetensi ini dianggap penting untuk dimiliki seseorang ketika memasuki dunia kerja; Keempat, Global Citizenship as the cultivation of principled decisionmaking yaitu bahwa kewarganegaraan global memerlukan kesadaran akan interdependensi dari individu-individu dan sistem-sistem serta rasa tanggung jawab bersama yang dilahirkannya. Kelima, Global citizenship as partisipation in a social and political life of one's community, yaitu bahwa kewarganegaraan global mensyaratkan partisipasi seseorang pada bermacammacam tipe masyarakat dari mulai lokal hingga global, dari kemonitas keagamaan hingga komunitas politik. Partisipasi inilah yang berupakan dimensi aktual dari rasa tanggungjawab atas pilihan-pilihan personal yang meliputi voting, volunteering, advocacy, dan berbagai aktivitas politik menyangkut isu lingkungan, kemiskinan, perdagangan, kesehatan atau hak asasi manusia (2012, hlm. 1-2).

Konsep global citizenship (kewargaaan global) bukanlah barang baru. Tahun 450 Socrates telah meenyatakan bahwa tanah yang ia 
tinggali adalah bagian dari dunia (origin to be the world). Satu abad kemudian, Diogenes mendeklarasikan diri sebgaai warga dunia. (Morais dan Ogdon dalam Carabain et all, 2012). Meskipun dimensi global pada kewarganegaraan telah lahir jauh sejak dulu, namun konsep tersebut belum mengalami perkembangan menjadi definisi secara formal. Namun, dimensi moral dari kewarganegaraan global telah banyak dirumuskan. Dimensi ini berfokus pada kontribusi individu yang pada prinsipnya bertujuan membuat dunia menjadi lebih baik. Individu dilekatkan pada hak dan kewajiban satu sama lainnya melalui aksi voluntarisme sipil terlepas dari otoritas politis apapun (Dower, 2010 dalam Carabain et al, 2012).

Menurut Murdiono (2014) ada tiga dimensi utama yang sering disebut dalam kewargaan global, yakni (1) tanggungjawab sosial (social responsibility); (2) kompetensi global (global competence); dan (3) keterlibatan dalam kewargaan global (global civic engagement). Kesatu tanggung jawab sosial dimaknai sebagai tingkat kesadaran saling ketergantungan dan kepedulian sosial kepada orang lain, masyarakat dan lingkungan.. Kedua kompetensi global dimaknai sebagai kemampuan memiliki pemikiran terbuka dan secara efektif berusaha memahami norma-norma budaya orang lain dan memanfaatkan penegtahuan yang dimiliki untuk berinteraksi, berkomunikasi dan berekerja sama. Ketiga keterlibatan dalam kewarganegaraan global (civic engagement) dimaknai sebagai tindakan atau kecenderungan untuk mengenali masalahmasalah kemasyaraktan baik di tingkat kokal, nasional dan global dengan ikut serta dalam aktivitas dan partisipasi masyarakat.

Inti dari warga negara global adalah civic engagement atau pelibatan warga negara. Melalui pelibatan warga negara, individu sebagai warga negara dari komunitas mereka, negara mereka dan dunia dapat diberdayakan sebagai agen perubahan sosial untuk dunia yang lebih demokrartis. Pelibatan warga negara meliputi beberapa tindakan, yakni : belajar dari orang lain, diri, dan lingkungan untuk mengembangkan perspektif informasi dan isu sosial; menghargai perbedaan; bertingkah dan bekerja dengan kesopanan; mengambil peran aktif dalam kegiatan politik; berpartisipasi aktif pada kehidupan publik, pemecahan permasalahan publik dan melayani komunitas; memiliki sikap kepemimpinan pada sebuah organsasi; mengembangkan empati, etika, nilai-nilai dan merasakan tanggung jawab sosial; dan mempromosikan keadilan sosial lokal dan global (Jacoby, 2009, hlm. 9).

Krisis kemanusiaan hingga detik ini masih memerlukan perhatian warga global. Gerzon (2010) mengemukakan masyarakat global sedang dihadapkan pada tiga isu global yang paling krisis. Isu-isu tersebut meliputi: (1) isu perdamaian dan kemanusiaan; (2) isu kemiskinan; dan (3) isu lingkungan hidup. Artikel ini akan berfokus pada isu pertama sebagai masalah global yang harus direspon oleh tanggungjawab global citizen. Sejumlah krisis kemanusiaan terjadi di negara-negara Timur Tengah terdampak koflik negara seperti Palestina, Suriah, Yaman, Negaranegara miskin di Afrika, beberapa kelompok etnis yang tengah dilanda konflik seperti Rohingya, dan Uighur. Kondisi ini menunjukkan sebuah ironi ditengah kesepakatan warga dunia untuk mempromosikan dan menghargai HAM seperti yang tertuang dalam DUHAM, dan ditengah komitmen manusia Indonesia untuk hidup pancasilais yag menjunjung tinggi HAM. 


\section{METODOLOGI}

Penelitian ini menggunakan pendekatan kualitatif dengan desain studi deskriptif. Penelitian kualitatif dipilih karena penelitian ini bermaksud meneliti kondisi obyek yang alamiah, (sebagai lawannya adalah eksperimen) dimana dalam prosesnya peneliti menjadi instrumen kunci (Sugiyono, 2009, hlm. 1). Tujuan dari dipilihnya penelitian kualitatif, yaitu untuk memahami fenomena-fenomena sosial yang terjadi dari sudut pandang partisipan. Sementara itu alasan pemillihan desain deskriptif adalah karena melalui desain ini, peneliti dapat memperoleh gambaran sekelompok manusia, suatu objek, suatu kondisi, suatu sistem pemikiran atau sesuatu pada masa sekarang (Nazir, 2005). Pengumpulan data dilakukan melalui sejumlah pengamatan (observasi), wawancara, dan studi terhadap pelbagai literatur atau dokumen. Pengamatan dilakukan terhadap aktivitas kelembagaan dalam menjalankan program. Wawancara dilakukan terhadap beberapa partisipan yang peneliti pilih secara purposive yaitu pengurus lembaga kemanusiaan global ACT dan pegiat sosial dan kemanusiaan ACT. Adapun analisis dokumen dilakukan terhadap dokumen kelembagaan, laporan pertanggungjawaban program tahunan, litelatur lain yang relevan untuk menunjang perolehan data. Data yang terkumpul kemudian dianalisis dengan menggunakan teknik reduksi data, display data, dan verifikasi/ penarikan kesimpulan sebagaimana dikemuakakan oleh Miles dan Huberman (1992). Data diuji melalui validitas data berupa triangulasi baik itu triangulasi sumber maupun triangulasi teknik.

\section{PEMBAHASAN}

\section{Upaya ACT dalam Penguatan Global Engagement Warga Negara di Indonesia}

Dalam merespon krisis kemanusiaan global, beberapa upaya telah ditempuh oleh negara dengan kebijakan dan politik luar negeri. Namun, gerakan-gerakan kemasyarakatan juga memiliki tidak kalah penting bahkan mungkin cenderung bisa lebih diandalakan. Gerakan sosial sepatutnya bukan dipandang sebagai suplemen saja, namun justru inti dari pembangunan sosial. Gerakan sosial menandai bahwa kepedulian sosial warga daam suatu negara sudah berada pada tingkatan yang mapan. Namun, di Indonesia, masih terdapat stigma bahwa keterlibatan individu sulit untuk distimulus karena masih rendahnya kesadaran dan jikapun ada, sulit berpengaruh terhadap perubahan karena sumber daya yang dihasilkan masih minim. Temuan yang akan dilaporkan dalam artikel ini adalah terkait fenomena tergalangnya keterlibatan global (Global engagement) warga negara melalui program sukarela yang dikembangkan oleh lembaga Aksi Cepat Tanggap.

Hakikatnya, gerakan sosial diharapkan mampu mengaktualisasikan dan mengembangkan global engagement. Kehadiran civic community yang mampu menjawab tantangan revolusi industri 4.0 dibidang community developmen sangat diperlukan. Misalnya yang berhasil mengembangkan ruang gerak aktivitasnya melalui media sosial dan fasilitas web 2.0 untuk mempersuasi keterlibatan masyarakat. Kita ketahui bahwa internet dewasa ini dapat diklaim sebagai saluran komunikasi dan informasi terpopuler menyalip media maistream seperti televisi, radio Aksi Cepat Tanggap peneliti pilih sebagai 
subjek observasi dan subjek kajian karena aktivitasnya peneliti anggap telah mampu membangkitkan keterlibatan warga negara melalui pengembangan program filantropi dan voluntarismenya. ACT secara resmi diluncurkan sebagai yayasan yang bergerak di bidang sosial dan kemanusiaan pada 2005. Untuk memperluas karya, ACT mengembangkan aktivitasnya, mulai dari kegiatan tanggap darurat, kemudian mengembangkan kegiatannya ke program pemulihan pascabencana, pemberdayaan dan pengembangan masyarakat, serta program keagamaan seperti Qurban, Zakat dan Wakaf. Visi ACT ialah menjadi organisasi kemanusiaan global profesional berbasis kedermawanan dan kerelawanan masyarakat global untuk mewujudkan peradaban dunia yang lebih baik. Adapun misinya ialah (1) mengorganisir dan mengelola berbagai persoalan kemanusiaan secara terencana, terkonsep, terintegrasi, dan berkesinambungan sehingga menjadi formula ideal dalam mengatasi berbagai problem kemanusiaan baik dalam skala lokal, nasional, regional, maupun global; (2) mengorganisir dan mengelola segala potensi kedermawanan masyarakat global sebagai modal sosial untuk mengatasi berbagai problem kemanusiaan baik dalam skala lokal, nasional, regional, maupun global; (3) mengorganisir dan mengelola segala potensi kerelawanan global sebagai modal sosial untuk mengatasi berbagai problem kemanusiaan baik dalam skala lokal, nasional, regional, maupun global.

Sejak tahun 2012 ACT mentransformasi dirinya menjadi sebuah lembaga kemanusiaan global, dengan jangkauan aktivitas yang lebih luas. ACT mengembangkan jejaring dalam bentuk representative person sampai menyiapkan kantor ACT di luar negeri. Jangkauan aktivitas program global sudah sampai ke 22 Negara di kawasan Asia Tenggara, Asia Selatan, Indocina, Timur Tengah, Afrika, Indocina dan Eropa Timur. Wilayah kerja ACT di skala global diawali dengan kiprah dalam setiap tragedi kemanusiaan di berbagai belahan dunia seperti bencana alam, kelaparan dan kekeringan, konflik dan peperangan, termasuk penindasan terhadap kelompok minoritas berbagai negara.

Terdapat 6 (enam) program kemanusiaan global yang diorganisir oleh ACT. Program-program tersebut meliputi:

(1) Let's Save Palestine, Sejak tahun 2009, Aksi Cepat Tanggap mewakili bangsa Indonesia sudah hadir membersamai warga Palestina dengan berbagai aksi dan program. Berbagai program berkelanjutan ACT yang bahan bakunya tidak lain ialah keterliatan warga negara secara materil amupun moril terus berjalan dalam membantu warga Palestina. Diantaranya adalah Mobile Water Tank dan Waterwell (sumur air) yang dibangun di Jabalia Utara. Kemudian pemberian generator listrik beserta bahan bakar solar dalam beberapa tahap untuk pemukiman, klinik kesehatan, dan sekolah. ACT juga telah mengembalikan penghidupan masyarakat Gaza melalui pembuatan peternakan ayam dan pembuatan kapal nelayan. Dalam bidang kesehatan ACT setiap tahunnya secara bertahap menyalurkan amanah rakyat Indonesia dalam bentuk pembangunan klinik kesehatan, pemberian mobil ambulans, peralatan medis, kursi roda, hingga bantuan persalinan untuk kaum hawa di Gaza. Setiap tahunnya dalam beberapa periode ACT juga mengimplementasikan donasi dari Indonesia guna memenuhi kebutuhan dasar pangan masyarakat Palestina. Diantaranya merupakan pemberian paket pangan berisi sembako, pembagian daging qurban, distribusi tepung gandum, 
bingkisan lebaran, dan pembagian ifhtor siap saji pada bulan Ramadhan;

(2) Let's Help Syria, dalam merespon krisis kemanusian di Suriah, ACT mendistribusikan bantuan masyarakat yang tergalang secara daring dan luring melalui kampanye gerakan kemnausiaan. Tidak hanya bantuan materil seperti paket pangan, bantuan musim dingin yang rutin dikirimkan, dana pendidikan membangun sekolah dan beassiwa bagi anak-anak yang terdampak, atau kiprak dalam menciptakan kamp pengungsian yang lebih layak baik baik bagi fisik maupun psikis. Beberapa pabrik roti juga dibangun untuk membuka lapangan kerja warga disana, termasuk relawan dan tim yang dikirimkan. Relawan banyak berkiprah dibidang medis, pelayanan sosial, trauma healing, pendidikan dan lain sebagainya. ACT telah menjadi penyalur sumber daya warga negara Indonesia untuk membantu warga Suriah dalam berbagai aspek. Relaan Indoensia membantu para korban untuk bertahan hidup ditengah tiadanya bantuan dari pemerintah Suriah dan absennya negara untuk memberi suaka bagi warganya sendiri.

(3) Let's Help Rohingya, Pada tahun 2012, muncul gerakan Rohingya Elimination Group yang didalangi oleh kelompok ekstremis 969. Konflik yang pecah memakan 200 jiwa dan 140.000 warga Rohingya lainnya dipaksa tinggal di kamp-kamp konsentrasi yang tidak manusiawi. Menurut sebuah studi oleh International State Crime Initiative (ISCI) dari Queen Mary University of London, Rohingya sudah mulai memasuki tahap akhir genosida yaitu pemusnahan massal dan penghilangan dari sejarah. PBB juga menyebut Rohingya sebagai kelompok etnis paling teraniaya di dunia.Saat ini Muslim Rohingya yang masih berada di Rakhine hidup terisolasi dalam ketakutan. Sejak tahun 2013 lalu, ribuan warga melarikan diri ke negara-negara Indonesia, Malaysia, dan Thailand melalui jalur laut. Pria, wanita, dan anakanak terkatung-katung di dalam kapal tanpa kejelasan apakah daratan yang mereka tuju bersedia menerima mereka. Salah satu pengungsian warga Rohingya di Indonesia dibangun oleh Yayasan Aksi Cepat Tanggap berlokasi di Blang Adoe, Aceh Utara. Berkat bantuan yang tergalang dari masyarakat, ACT membnagun kamp yang lebih layak. Tidak hanya itu, beberapa program dibuat khusus untuk tujuan pemberdayaan bukan hanya sekadar bantuan materil saja. Misalnya, pendidikan, atau modal bagi mereka untuk bermata pencaharian agar bisa lebih produktif kedepannya.

(4) Winter Aid, Melalui program winter Aid, ACT menyalurkan bantuan warga negara Indonesia bagi warga Palestina dan Suriah untuk menghadapi musim dingin. Bantuan diberikan dlaam bentuk paket musim dingin baik untuk korban konflik si Suriah, Yaman, maupun Pelstina. Bantuan biasnaya diberikan dlam bentuk sandang, pangan dan papan. Tujuannya agar mengurangi penderitaan warag disana dalam menghadapi musim dingin. Bantuan dihasilkan dari pelbagai program filantropi dan tergalang dari gerakan kampanye kemansuiaan yang dilakukan oleh para pegiat kemanusiaan ACT.

(5) Food For Yemen \& Somalia, Somalia masih terjebak dalam konflik yang berlarut sejak tahun 70-an, penyakit mematikan yang mendera, kekeringan ekstrim, hingga ekonomi yang tak berkembang bergumul kekalutan dan kemiskinan. Kemiskinan di negeri ini menembus level $82 \%$ dari jumlah penduduk. Standar hidup masyarakat rendah, fasilitas kesehatan memprihatinkan, dan kondisi pendidikan nyaris tidak terperhatikan. Krisis pangan tahun 2011 silam, memakan korban jiwa mencapai seperempat juta penduduk 
negeri. Gizi buruk merebak, tubuh anakanak bak tulang berselimut kulit. ACT telah menyalurkan amanah bantuan kemanusiaan bangsa Indonesia bagi saudara-saudara kita di Yaman dan Somalia. Bahkan untuk Somalia, tim kemanusiaan ACT yang mengemban misi \#FoodForSomalia di tahun 2011, menjadi "pembuka jalur" bagi NGO-NGO lain dalam menyalurkan bantuan kemanusiaan.

(6) Bebaskan Uighur Berislam, Belakangan ini, penderitaan masyarakat etnis Uighur tengah menjadi sorotan dunia. Mereka mengalami penindasan, persekusi, diskriminasi, serta perlakuan tidak adil oleh pemerintah Republik Rakyat Cina.Uighur adalah etnis masyarakat yang mayoritas beragama Islam yang berasal dari daerah Xinjiang, Cina. Mereka diperlakukan dengan kejam karena pilihannya untuk memeluk dan mengamalkan agama Islam. Perlakuan tersebut bahkan dipusatkan dalam kamp konsentrasi yang berkapasitas jutaan jiwa dengan dikelilingi tembok tinggi, menara pengawas, kamera CCTV dan penjaga bersenjata. Aksi Cepat Tanggap (ACT) akan merespon kekejian terhadap saudara-saudara kita etnis Uighur. ACT akan menyalurkan bantuan bagi etnis Uighur yang mengungsi di beberapa lokasi di luar Xinjiang.

Disamping keenam program kemanusiaan global tersebut, ACT juga menyususn program-program insidental dan tentatif dengan melihat dan mempertimbangkan gejala kemanusiaan yang berlangsung. Selain melalui program-program bantuan langsung, Berdasarkan hasil pemantauan peneliti terhadap aktivitas kelembagaan ACT didapat hasil bahwa Lembaga Kemanusiaan Global ACT secara aktif memfasilitasi warga negara Indonesia dalam mengaktualisasikan global engagement warga negara melalui cara- cara yang dapat dijelaskan sebagai berikut:

\section{Sosialisasi pelbagai tragedi dan krisis kemanusiaan global}

Berdasarkan hasil observasi, peneliti memperoleh temuan bahwa ACT secara aktif merupakan media informasi dalam menyiarkan berbagai berita tentang krisis dan tragedi kemanusiaan global yang sedang berlangsung. Penyebaran informasi banyak dilakukan pada latar daring. ACT memiliki platform online dalam mensosialisasikan berbagai berita kemanusiaan global seperti melalui (1) media sosial meliputi instagram (IG TV, IG posts, IG Story), Facebook, dan Twitter; (2) aplikasi perpesana daring (online messenger Aplication) seperti Whatsapp; (3) melalui email pada donatur atau pengikut akun resmi ACT; (4) situs belanca Online; (5) Kanal Youtube ACT (ACT TV); (6) platform online act.id yang didalamnya ACT mengembangkan media informasi berupa Emagz. Emagz adalah majalah elektronik yang dimiliki ACT terdiri dari bentuk News Letter, Majalah, dan Tabloid yang diterbitkan secara berkala. Berdasarkan data tersebut maka dapat ditaksir bahwa setiap harinya masyarakat khususnya warga net di Indonesia terpapar oleh berita kemanusiaan ACT. Hal ini penting karena kesadaran sebagai warga global serta pemahaman global diawali oleh wawasan global. Salah satunya ialah isuisu kemanusiaan global terkini. Dengan pengetahuan tersebut, diharapkan mampu membangkitkan semangat kemanusiaan waraga negara Indonesia agar bisa terlibat lebih jauh dalam merespon krisis kemanusiaan global yang terjadi.

\section{Filantropi Global}

Filantropi dalam konteks ini adalah helping behavior yang termanifestasikan dalam bentuk materil. Filantropi dikampanyekan oleh ACT 
melalui kegiatan penggalangan dana langsung, platform online berbasis web.2.0 maupun media sosial. Dalam mengembangkan aktivitas kemanusiaannya, ACT didukung oleh donatur publik dari masyarakat yang memiliki kepedulian tinggi terhadap permasalahan kemanusiaan dan juga partisipasi perusahaan melalui program kemitraan dan Corporate Social Responsibility (CSR). Segala bantuan langsung yang tersalurkan dalam program-program sebagaimana telah diuraikan adalah hasil dari praktik filantropi yang dikampanyekan oleh ACT dan secara nyata adalah bentuk keterlibatan warga negara. Karakter kepedulian sosial manusia Indonesia, dalam hal ini dapat terbina dan teraktualisasikan sebagai spirit kemanusiaan.

\section{Voluntarisme Global}

Ketika menemukan istilah voluntarisme, secara definitif para ahli banyak mengidentikannya dengan tindakan memberikan pertolongan (helping behaviour. (Kemp, 2002, Batson, 1991). Hal ini juga diperteas oleh Wilson (2000) yang menyatakan bahwa voluntarisme adalah bentuk spesifik dari sikap dan tindakan menolong yang melibatkan komitmen jangka panjang. Ketika menemukan istilah voluntarisme, secara definitif para ahli banyak mengidentikannya dengan tindakan memberikan pertolongan (Kemp, 2002, Batson, 1991). Hal ini juga diperteas oleh Wilson (2000) yang menyatakan bahwa voluntarisme adalah bentuk spesifik dari sikap dan tindakan menolong yang melibatkan komitmen jangka panjang. ACT mengembangkan jejaring dalam bentuk representative person. ACT mengirim relawan-relawan yang secara sukarela melakukan kegiatan pelayanan sosial bagi korban-korban krisis kemanusiaan yang tersebar di berbagai belahan dunia. Aktivitas kemanusiaan ini memposiskan Lembaga Kemanusiaan Global ACT sebagai civic community yang tidak hanya mampu melakukan penguatan global civic engagement, tetapi juga mampu membangun jejaring transnasional, dan sebagai inovator model alternatif pembangunan masyarakat berbasis solidaritas global.

\section{PENUTUP}

Peran lembaga kemanusiaan
global ACT menguatkan global engagement warga negara dalam rangka merespon krisis kemanusian global ialah merancang mengoperasikan dan mengkampanyekan program-program yang memfasilitasi partisipasi lokal dan global. Program filantropi dan voluntrisme global diorganisisr untuk kemudian mengarah pada aksi-aksi kolektif dalam rangka pembangunan pada bidang kemasyarakatan, kemanusiaan, dan pendidikan. dikembangkan melalui pemanfatan digital, sejumlah prinsip yang ACT terapkan yaitu ialah praktis, efisien, fleksibel, akuntabel, dan aktual. Program-program kemanusiaan ACT telah memfasilitasi partisipasi lokal dan global. Dengan demikian, kewarganegaraan lokal dan global secara unik terkait dengan partisipasi warga negara dalam gerakan sosoial ACT dan bahwa pengembangan berbasis digital memainkan peran penting dalam proses ini dengan menumbuhkan rasa kewarganegaraan dalam konteks lokal dan global. Keterlibatan publik pada program-program berskala global meliputi global zakat, global wakaf, global qurban adalah aktualisasi kewarganegaraan global.

Pada sektor lapangan ilmu, penelitian ini ini telah menyumbang konsep dan teori tentang pembinaan keterlibatan global dna penguatan kewarganegaraan global melalui gerakan sosial berskala global. Studi ini telah 
menjelaskan posisi dan kekuatan masyarakat dalam rangka pemecahan masalah-masalah sosial kemanusiaan pada tingkat global yang berkombinasi dengan pemanfaatan digital. Secara teoretis hasil penelitian dapat memberikan kontribusi terhadap pengembangan keilmuan $\mathrm{PKn}$ terkait desain dan model pendidikan kewarganegaraan pada domain sosiokultural yang layak dan berpengaruh terhadap perubahan dan perbaikan taraf hidup masyarakat trans-nasional. Pada sektor kewargangeraan, sosial, dan pendidikan, penelitian ini diharapkan mampu meberikan gambaran tentang global engagement yang berhasil dikembangkan. Studi ini juga menjelaskan pola-pola pengembangan dan pendekatan untuk mempersuasi atau memobilisasi massa di era revolusi digital. Ini penting karena pada hakikatnya keterlibatan warga negara adalah potensi utama dalam membangun demokrasi dan masyarakat madani. Gagasan ini dapat pula diaplikasikan pada gerakan-gerakan di bidang lainnya seperti voluntarisme politik, gerakan kepemudaan, gerakan lingkungan, gerakan literasi dan lain sebagainya. Namun, tentunya perkembangan tersebut harus diimbangi dengan regulasi yang memadai. Karena kebijakan dan hukum pada hakikatnya harus turut mengikuti semangat zaman atau bahkan mejadi prediktor. Pada aspek pendidikan, hasil penelitian ini menjadi refleksi bagi penguatan kurikulum kewarganegaraan berbasis global citizenship, digital citizenship dan service learning

Kami menyampaikan terima kasih yang tulus kepada Aksi Cepat Tanggap yang mengizinkan kami melakukan studi tentang kegiatan organisasi dan gerakan tersebut. Terima kasih kepada semua partisipan penelitian yang mengecualikan relawan ACT dan pengasuh ACT yang bersedia diwawancarai oleh para peneliti.

\section{DAFTAR PUSTAKA}

Adler, R. P., \& Goggin, J. 2005. What Do We Mean By "Civic Engagement"? Journal of Transformative Education, 236253.

Affandi, Idrus. (2009). Bedah Buku Pendidikan Politik dari Robert Brownhill dan Patricia Smart. Bandung: Kencana Utama

Batson. C.D. 1991 Why Act for the public good? For Answers. Personality, and Interpersonal correlas of non spontaneous helping behavior. Journal for the theory of social behaviour. 39 (3). 34-50.

Basyuni, Muhammad Muzzamil. 2016. Peran Indonesia Dalam Penyelesaian Konflik Timur Tengah (Kasus Konflik Israel Palestina). Disertasi SPS UGM. Tidak Diterbitkan.

Brusbridge, Rachel. 2017. IsraelPalestine and the Settler Colonial 'Turn': From Interpretation to Decolonization. Jurnal Sage Publication Theory Culture and Society 201735 (1). 91-115.

Carabain, Christine, dkk. 2012. Global Citizenship: From Public Support To Active Participation. Amsterdam: NCDO.

Carpini, M. D., \& Keeter, S. 1996. What Americans Know about Politics and Why it Matters. New Haven, CT: Yale University Press.

Dewantara, Ramma Wisnu dan Derajad S Widhyharto. 2015. Aktivisme dan Kesukarelawanandalam Media Sosial Komunitas Kaum Muda Yogyakarta. Jurnal Ilmu Sosial dan Politik UGM.19 (1). 40-52. ISSN 1410-4946 
Ehrlich, T. 2000. Civic Responsibility and Higher Education. Phoenix, AZ: Greenwood Publishing Group.

Eckendrode, John. dkk. 2015. Systematic Traditional Review: Volunteer Motivation. Bronfrnbrenner Center for Translational Research.

Gerzon, Mark. 2010. Global Citizen: How Our Vision of The World Is Outdated and What We Can Do About It. London: Ebury Digital.

Green, F. Madaleine. 2012. Global Citizen: What Are We Talking About and Why Does it Matter. Trend And Insight For International Education Leaders. 1-4

Grugel, J. 2000. Romancing civil society: European NGOs in Latin America. Journal ofInteramerican Studies \& World Affairs, 42(2), 87-107

Hendrastomo, Gendi. 2007. Nasionalisme vs Globalisme: Hilangnya Semangat Kebangsaan dalam Peradaban Modern. Jurnal Demensia. 1 (1). 1-11.

Hoskins, B. L., \& Mascherini, M. 2009. Measuring Active Citizenship through the Development of a Composite Indicator. Social Indicators Research, 90(3), 459488.

Indianngo. 2003. What is an NGO? (Online)(http://www.indianngos $. \mathrm{com} / \mathrm{n} \quad$ gosection/newcomers/whatisanngo.htm, diakses 12 Desember 2007).

Jacoby, B. 2009. Civic Engagement In Higher Education: Concepts And Practices. San Francisco: Jossey-Bass.

Jati. 2016. Cyberpsace, Internet dan Ruang Publik Baru: Aktivisme Online Politik Kelas Menengah
Indonesia. Jurnal Pemikiran Sosiologi UGM

Kalidjernih, Freddy. K. 2013. Puspa Ragam Konsep Dan Isu Kewarganegaraan. Bandung: Widya Aksara Press.

Kemp, S. 2002. The Hidden Workforce: Volunteering learning in the olympics. Journal of European Industrial Training. 26 (1). 109116.

Laclau, Ernest dan Chantal Mouffe. 2001. Hegemony and Socialist Strategy: Toward a Radical Democratic Politics.. London: Verso (New Left).

Lawry, S., Laurison, D. L., \& VanAntwerpen, J. 2006. Liberal Education and Civic Engagement: A Project of the Ford Foundation's Knowledge, Creativity and Freedom Program. Ford Foundation.

Marcussen, H. S. 1996. Ngos, The State, And Civil Society. Review of African Political Economy. 23(69), 405-423.

Pancer, S. M. 2015. The Psychology of Citizenship and Civic Engagement. New York: Oxford University Press.

Permana, Aditya \& Risyad M.Prawira. 2016. Kontribusi Aktivitas Voluntaristik Kaum Muda terhadap Sosialisasi dan Institusionalisasi Identitas Regional Asia Tenggara Melalui ASEAN Youth Voluntary Program (AYVP) 2013 - 2016. Jurnal Studi Pemuda.5 (2). 467 486

Willet, Peter. 1996. The Conscience of The World: The Influence of Non Governmental Organization in the UN System. Washington DC: Broocking Institute. 
Yamin, F. 2001. NGOs and international environmental law: A critical evaluation of theirroles and responsibilities. RECEIL, 10, 149-162.

Antara. 2014. Masalah Sosial Garapan Kementerian Sosial. [online] Diakses dari http://www.antaranews.com. (3 Desember 2018)

Kementerian Komunikasi dan Informatika RI. 2018. Infografis Penetrasi Pengguna Internet di Indonesia. [online]. Diakses dari http://www.kominfo.go.id. (3 Desember 2018).

Tim Kompas. 2016. Korban Konflik Global. [online] Diakses dari http://nasional.kompas.com. (3 Desember 2018).

Undang-Undang Dasara Negara Republik Indonesia Tahun 1945

Undang-Undang Republik Indonesia Nomor 12 Tahun 2005 Tentang Ratifikasi Kovenan Internasional tentang hak sipil dan politik. 